\title{
O MOVIMENTO CIVIL-MILITAR DE 1964 E OS INTELECTUAIS
}

\author{
José LuÍS SANFELICE*
}

RESUMO: Este estudo deseja captar no movimento da história, em uma conjuntura determinada, tensões que opuseram diferentes sujeitos sociais dos anos de 1970, no Brasil. Em um dos pólos localiza-se o pensamento expresso pelos primeiros governantes do movimento civil-militar que ocuparam o aparelho de Estado em 1964. Humberto Castelo Branco, presidente da República, Flávio Suplicy de Lacerda, ministro da Educação e Cultura, e Raymundo Moniz de Aragão, com seus pronunciamentos no V Fórum Universitário, encarregaram-se de transmitir o pensamento do governo à sociedade. $\mathrm{Na}$ sequência, em curto espaço de tempo, os reflexos apareceriam no aparato legal da reforma universitária consentida. $\mathrm{O}$ contraponto à visão oficial encontra-se, para fins deste trabalho, em um texto da época de autoria de Florestan Fernandes e que resultou da conferência proferida na abertura do I Fórum de Professores, realizado no Rio de Janeiro em 1968. Espera-se, analisando o conflito ideológico, alcançar uma compreensão crítica mais acurada do movimento civil-militar de 1964 e das suas relações com diferentes intelectuais.

Palavras-chave: Movimento de 1964. Reforma universitária. Intelectuais. Movimento estudantil. Florestan Fernandes.

\section{The 1964 CIVIL-MILITARY MOVEMENT AND THE INTELLECTUALS}

ABSTRACT: This study aims to identify, within the movement of history in a given conjuncture, tensions that have opposed several social characters of the 1970 s, in Brazil. The thinking expressed by the first leaders of the civil-military movement that * Doutor em Educação e professor titular em História da Educação, na Faculdade de Edu-
cação da Universidade Estadual de Campinas (UNICAMP). E-mail: sanfelice00@hotmail.com 
took over the State apparatus in 1964 represents one pole. Through their speeches at the V University Forum, Humberto de A. Castelo Branco, President of the Republic, Flávio Suplicy de Lacerda, Minister of Education and Culture, and Raymundo Moniz de Aragão, communicated the government's views on education to the society. These would be very soon included in the legal regulations of the University Reform. For this work, the opposite pole to this official vision is a historical writing by Florestan Fernandes produced after the lecture he gave at the opening of the I Professors' Forum, held in 1968 in Rio de Janeiro. Analyzing this ideological conflict, we hope to reach a more accurate critical understanding on the 1964 civil-military movement and its relationships to different intellectuals.

Key words: 1964 movement. University reform. Intellectuals. Student movement. Florestan Fernandes.

\section{Introdução}

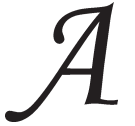

ditadura civil-militar instaurada pelo Movimento de 1964, urdida ao longo das décadas anteriores, apenas dava os seus primeiros passos no poder. Quase que de imediato ao golpe, ela procurou uma autodefinição que a justificasse. Com desfaçatez anunciou, no Ato Institucional n. 1 (AI-1), de 9 de abril daquele ano:

É indispensável fixar o conceito do movimento civil e militar que acaba de abrir ao Brasil uma nova perspectiva sobre o seu futuro. O que houve e continuará a haver neste momento, não só no espírito e no comportamento das classes armadas, como na opinião pública nacional, é uma autêntica revolução. (Campanhole \& Campanhole, 1981, p. 309)

O golpe aplicado contra boa parte dos cidadãos, pelo AI-1, transformou-se em "autêntica revolução". E, apesar das evidentes provas em contrário, a "opinião pública nacional" foi considerada única. As palavras se sobrepunham à realidade: "A revolução se distingue de outros movimentos armados pelo fato de que nela se traduz não o interesse e a vontade de um grupo, mas o interesse e a vontade da Nação" (idem, ibid.).

Dada a pretensa unidade de interesses e da "vontade da Nação", cabe indagar: por que, então, foi necessário o golpe ou, segundo os golpistas, a revolução? 
As respostas e justificativas eram bem focalizadas. Fica-se sabendo, nos parágrafos posteriores do AI-1, que o apoio da Nação ocorrera não na sua totalidade, mas sim "na sua quase totalidade". E a qual minoria o AI-1 se referia? Ao governo destituído de João Goulart, "que deliberadamente se dispunha a bolchevizar ${ }^{1}$ o País". Era preciso "tomar as urgentes medidas destinadas a drenar o bolsão comunista, cuja purulência já se havia infiltrado não só na cúpula do governo, como nas suas dependências administrativas". Como "os processos constitucionais não funcionaram para destituir o governo", os golpistas, agora travestidos de revolucionários, o fizeram. Era, sem dúvida, uma excelente explicação para quem não se acostumara minimamente a conviver com uma democracia, ainda que pífia, mas que legitimava o governo de João Goulart. ${ }^{2}$

A revista $O$ Cruzeiro (10 de abril 1964) trouxe declarações de governadores envolvidos no golpe. O governador de São Paulo, Adhemar de Barros, por exemplo, afirmou:

(...) combate sem trégua aos comunistas, caçando-os onde estiverem, em qualquer ponto do território nacional (...). Quando vocês todos estavam dormindo, sonhando com a liberdade, nós já mandávamos os primeiros comunistas para a Casa de Detenção. Mas à velha Casa de Detenção, pois não tem mais direito nem à cadeia nova (...). [No governo de Goulart] mandavam os pelegos, os estudantes vermelhos, os camponeses doutrinados e os escravos de Moscou. Agora, caçaremos os comunistas por todos os lados do País. Mandaremos mais de 2000 agentes comunistas numa verdadeira Arca de Noé - para uma viagem de turismo à Rússia. Mas uma viagem que não terá volta. Que falem em democracia, agora, na Rússia. Não deporemos armas enquanto não expulsarmos toda a canalha vermelha. Caçaremos os mandatos de todos os parlamentares, governadores e prefeitos comunistas (...). Vamos começar imediatamente o expurgo dos comunistas. (Disponível em: <www.memoriaviva.com.br/ cruzeiro/10041964/199464 3.htm>)

Dentro de uma lógica cada vez mais ensimesmada, sempre disfarçando o autoritarismo, os golpistas proclamaram:

[só à revolução] cabe ditar as normas e os processos de constituição do novo governo e atribuir-lhe os poderes ou os instrumentos jurídicos que lhe assegurem o exercício do Poder (...). Fica, assim, bem claro que a revolução não procura legitimar-se através do Congresso. Este é que recebe deste Ato Institucional, resultante do Poder Constituinte, inerente a 
O movimento civil-militar de 1964 e os intelectuais

todas as revoluções, a sua legitimação. (Campanhole \& Campanhole, 1981, p. 309)

Praticamente ocorria um segundo golpe. O primeiro destituiu o Poder Executivo e o segundo tornou o Congresso subalterno. Mas, e daí? A premissa do autoritarismo já havia sido anunciada: "Assim, a revolução vitoriosa, como o Poder Constituinte, se legitima por si mesma”. A revolução forjada no papel adquiria o status de soberana e as Forças Armadas no Poder, conforme o AI-1, passavam a representar o povo. Que metas os novos representantes do povo se colocavam?

(...) reconstrução econômica, financeira, política e moral do Brasil, de maneira a poder enfrentar de modo direto e imediato, os graves e urgentes problemas de que depende a restauração da ordem interna e do prestígio internacional da nossa Pátria. (Idem, ibid.)

Era só o começo da ditadura civil-militar. A literatura especializada que se debruça sobre as origens, a instalação e a hegemonia alcançada pelo Movimento de 64 muito já produziu e, com certeza, nada ainda se esgotou.

No Dicionário Histórico-Biográfico Brasileiro (FGV-CPDOC, 2007) pode-se ver, no verbete "Revolução de 1964", que aquele movimento "acarretou profundas modificações na organização política do país, bem como na vida econômica e social". Fazendo ressalvas ao uso dos conceitos de "revolução" e "golpe", para caracterizar o Movimento de 64, acaba por defini-lo:

(...) regime militar autoritário, centralizador e burocratizante, mas de conseqüências econômicas modernizadoras, que, às expensas de forte compressão salarial e grande concentração de renda e capital, promoveram um tipo de desenvolvimento intimamente vinculado aos investimentos estrangeiros (...); um movimento político-militar conservador, em oposição às reformas de base "nacional-populistas" e à participação política de setores populares, tradicionalmente excluídos do pacto do poder. Enquanto expressão de interesses de classes - com expressiva mobilização dos grupos dirigentes e respaldo das classes médias, caracterizou-se pela rearticulação política do empresariado nacional, ligado ao capitalismo internacional, correspondendo internamente ao extrato moderno da burguesia industrial (...). (FGV-CPDOC, 2007) 


\section{O V Fórum Universitário}

Para os propósitos deste breve texto, queremos destacar que aquela ditadura civil-militar, fruto de alianças internas e externas ao país, representante de interesses da burguesia e do capital, das classes médias, não titubeou em expressar seus propósitos no que dizia respeito aos assuntos educacionais. Uma das suas manifestações iniciais ocorreu no transcurso do v Fórum Universitário, ${ }^{3}$ realizado em outubro de 1964, poucos meses, portanto, após o golpe.

O Ministério da Educação e Cultura, por iniciativa da Diretoria do Ensino Superior, publicou, em outubro de 1964, um opúsculo sob o titulo "A universidade e a revolução nacional". Agregaram-se nele três discursos pronunciados no transcorrer do v Fórum Universitário, considerados, no conjunto, a expressão do "pensamento do Governo resultante da revolução democrática, sobre o problema da Universidade e suas implicâncias no desenvolvimento econômico, na paz social e no futuro da nacionalidade" (MEC, 1964).

Os autores dos respectivos discursos foram: professor Flávio Suplicy de Lacerda, ministro da Educação e Cultura, que proferiu a aula inaugural do v Fórum; professor Raymundo Moniz de Aragão, diretor do Ensino Superior, que fez a saudação ao Presidente da República, em nome dos participantes, e o próprio Presidente da República, Marechal Humberto de Alencar Castelo Branco, que encerrou aquele evento.

A farsa histórica ia sendo montada. O título do opúsculo em questão contribuía para que ela se instalasse entre intelectuais, ao relacionar a universidade com a recente editada revolução nacional. Professores também já falavam pelo ou junto ao governo. $\mathrm{O}$ MEC usava $\mathrm{o}$ opúsculo para difundir o mito fundador instituído pelo AI- $1 .{ }^{4}$

O discurso inaugural da reunião (...), a saudação dirigida ao Presidente (...), e as palavras com que o Chefe do Governo encerrou solenemente o conclave assumem tal importância, que se fez imperioso impedir, a um tempo, ficassem limitados ao registro ruidoso mas efêmero dos jornais do dia, e ao registro perene mas abafante das atas oficiais.

Fazendo-os reunir em um mesmo opúsculo, para ampla divulgação, cumpre a Secretaria do Fórum Universitário o dever democrático de fazer saber 
à comunidade brasileira a doutrina e os rumos da ação política e técnica do Governo Revolucionário, com referência à magna questão do aperfeiçoamento das instituições universitárias. (MEC, 1964)

Os nobres propósitos aqui anunciados, sobretudo acerca das relações que a ditadura civil-militar já estava estabelecendo com intelectuais, instituições de ensino superior, universidades, professores e estudantes, não diminuem em nada a gravidade dos fatos acontecidos naquela conjuntura em que o autoritarismo se estruturava no poder. Basta recordar que imediatamente após o golpe, o prédio da União Nacional dos Estudantes (UNE) foi invadido, saqueado e queimado. Perderam-se, ali, entre outros, os documentos do Centro Popular de Cultura (СPC). No mês de abril daquele ano de 1964, a Universidade de Brasília (UnB), ainda em implantação, havia sido invadida por tropas da Polícia Militar que lá prenderam professores e estudantes. Na seqüência, a UnB passaria por forte intervenção.

O ministro da Educação e Cultura, professor Flávio Suplicy de Lacerda, autor do discurso da aula inaugural do v Fórum, naqueles primeiros meses da ditadura civil-militar, já se tornara visível ao movimento estudantil. $\mathrm{O}$ ministro, circulavam rumores, desejava extinguir a UNE. No V Fórum, entretanto, seu discurso pretendeu ser contundente, focando o que considerava o inimigo número um: o comunismo, a revolução comunista e os comunistas. Existissem ou não estes "avatares" do mal, neles residiam todos os perigos.

A revolução comunista só se fará pela Universidade inautêntica. Os comunistas têm bem ciência desta meridiana evidência, e sabem melhor ainda do que nós que há dois meios infalíveis, que se empregam em separado ou em conjunto, para fazer surgir da Universidade o Estado comunista: a massificação do estudante e a omissão do professor, um desleixo e um crime. (Idem, ibid.)

Contudo, o ministro não desejava reformar a universidade porque, segundo ele, a universidade ainda não estava formada. Falar em reforma era praticar uma perturbação semântica, "tão do gosto e do uso dos comunistas". O ministro explicitou, então, suas idéias de formação da universidade. $\mathrm{Na}$ base da instituição deve estar o homem,

(...) mas o homem suficientemente preparado e disposto a ser elemento basilar e não decorativo. Desta verdade elementar partiu este Governo 
Revolucionário da Republica para formar a Universidade, cuidando do elemento humano, disciplinando-o, porque não há vida universitária sem condição de propósitos sadios. O homem é o aluno e o professor, juntos e não separados, unidos e não desentendidos em lutas falsas de classes inexistentes. Inicia-se com a regulamentação legal dos órgãos de representação estudantil, já submetida ao Congresso Nacional, que visa a dar estrutura e garantir a dignidade permanente à vida do estudante como tal, protegendo-o contra aqueles que sabem, e bem, que a revolução comunista só poderá partir da Universidade inorgânica. (Idem, ibid.)

Os pretensos revolucionários de 1964 se autoproclamavam também os novos formadores da universidade brasileira. De quebra, disciplinando o elemento humano (alunos e professores) e protegendo os estudantes dos comunistas.

De acordo com o ministro Flávio Suplicy de Lacerda, queremos crer que, cometendo um crasso cochilo, a reforma legal revolucionária já fora feita pela Lei de Diretrizes e Bases da qual ele destaca alguns aspectos, ${ }^{5}$ entre eles, a concessão de autonomia às universidades. Recomendou que ela fosse usada com responsabilidade, referindo-se mais à disciplina, para conclamar que a universidade elaborasse "o pensamento da Nação". Todavia, antes que a universidade pudesse exercer o seu papel de elaborar "o pensamento da Nação", o ministro já concluía com um plural majestático: "estamos convencidos de tais verdades". "O Ministério da Educação já elaborou a sua reforma administrativa. Vai estudar os mercados de trabalho, marcar as zonas de influência das Universidades, planejar para elas, vai dar corpo e sentido à missão do ensino superior" (idem, ibid.).

Como, então, usar da autonomia legal? Talvez cumprindo a advertência final do ministro: "aliviem as Universidades de cargas humanas inúteis, sem contemplações (...)”; “(...) um vírus não vale pelo tamanho e nem pela quantidade, mas por ser vírus, que infecciona” (MEC, 1964).

O professor Raymundo Moniz de Aragão, encarregado de saudar o Presidente da República, presente no encerramento do V Fórum, revelou ter recebido "a alta e honrosa missão" do ministro da Educação, a quem é profundamente agradecido por isso. Ficamos sabendo também que a presença do Presidente Marechal era um "gesto de cortesia", pois os senhores reitores e diretores de escolas e faculdades haviam comparecido à sede do Governo, "para saudarem, na oportunidade 
de sua primeira reunião, após a restauração da ordem democrática, ao Supremo Mandatário da Nação" (idem, ibid.).

Após inúmeros encômios ao representante maior da ditadura naquele momento, o professor define o Fórum como uma vigília, para a "meditação dos graves e importantes problemas do ensino superior". Para ele, o desafio era o Brasil "crescer e fortalecer-se pela ciência e pela técnica (...)", mas havia o problema do alto índice de natalidade, segundo sua ótica: "a população brasileira cresce em ímpeto impressionante e avassalador, fenômeno que se impóe e domina toda a cena da vida nacional".

O professor Raymundo Moniz de Aragão, entretanto, tinha uma resposta pronta para seu problema e passou a servi-la a todos. É primorosa e merece ser transcrita integralmente.

Em trabalho valorizado pela sabedoria e um autêntico americanismo, realizado pelo Professor Frank Tiller, da Universidade de Houston, para a Academia Nacional de Ciências de Nova York, mostra aquele eminente mestre, apoiando-se em renomados economistas, que o estupendo progresso norte-americano, verificado nos últimos cem anos, não se pode atribuir aos investimentos convencionais ou aos aumentos de população e de território; antes, devem ser deferidos ao magnífico esforço realizado nos campos da educação e da pesquisa científica. Isto, para apontar às naçôes sul-americanas, que tão bem conhece e estima, a educação como o campo de investimentos a preferir; com vistas ao progresso, à estabilidade social, ao conforto e à segurança.

Mais preciso e objetivo, ainda, esclarece o ilustre homem de ciência, que se fez aos poucos atilado sociólogo, que é o ensino superior, dentre todas, a área prioritária de investimento, mesmo à vista de grandes massas analfabetas, por ser o que mais depressa influencia e acresce produtividade e libera o capital investido. Proclama, por fim, o que é evidência meridiana, serem o preparo dos mestres - que precede à expansão do próprio ensino - e o seu aperfeiçoamento, de fazer-se de cima para baixo. (idem, ibid.; grifos nossos)

Seguem-se novas revelaçōes do professor sobre os ajustes entre os órgãos oficiais para que os propósitos fossem alcançados, destacando-se o programa da CAPES para o aperfeiçoamento do pessoal docente. Todavia, para além de uma verborragia repleta de adjetivos e que semeia inclusive a visão que deveríamos ter hoje daqueles fatos, numa pretensão de que o passado projete para o futuro a maneira pela qual gostaria de 
se visto, um aspecto é bastante sugestivo: o poder nacional deveria ser composto por cinco pilares: forças econômicas, militares, psicossociais, políticas e a instituição universitária. Contudo, falando pelos participantes do Fórum, o autor do discurso arremata: "acordes se encontram e mutuamente se honram a Universidade e o Poder - prosperidade, segurança, concórdia, luz e liberdade".

O Marechal Presidente, ao encerrar o Fórum, foi objetivo: “é oportuno exprimir-vos o pensamento do Governo em matéria de tanta relevância” (MEC, 1964), ou seja, a vida universitária. Aponta, a seguir, algumas tarefas da universidade: preparar cidadãos de alto nível cultural, que impulsionem o desenvolvimento do país, e formar a consciência democrática das novas gerações.

Há, no discurso, palavras dirigidas aos estudantes e aos mestres. De um lado, o diagnóstico: "Bem sei, e isso é de vosso inteiro conhecimento, que, em tal movimento [estudantil, existem setores vinculados à subversão. Cumpre localizá-los e detê-los”. De outro lado, a solução por cooptação:

Mas, a verdade é que isso jamais será obtido por meio de leis, decretos ou regulamentos. O Governo não pode ser o fundamento da autoridade do corpo docente. Acima de tudo, ela deverá assentar nos conhecimentos de cada um, nas qualidades pedagógicas, na presença ativa e dominante face aos alunos.

(...) é indispensável contar-se com a integral colaboração dos professores. Os alunos, por circunstâncias diversas, podem errar; os seus mestres, no entanto, jamais podem fazê-lo. (Idem, ibid.).

A moeda de troca, naquela circunstância, olhada hoje à distância, parece-nos ter sido algo como a dedicação exclusiva à carreira de professor, o tempo integral e a remuneração condigna. Promessas que o Marechal Presidente disse estar no pensamento daquela administração, interessada em fazer da universidade uma verdadeira comunidade. Foram muitas as solicitações para que mestres e professores, nos seus respectivos papéis, vivessem em harmonia. Tudo em prol do progresso cultural do país.

Prometendo respeitar a liberdade de cátedra, a autonomia universitária, os professores e alunos, o Presidente diz com convicção: “(...) o Governo está certo de poder contribuir vigorosamente para o 
fortalecimento da vida universitária”. Garante a todos segurança e tranqüilidade à vida universitária.

Não tereis mais que temer o ambiente de subversão e inquietação no qual os objetivos políticos se sobrepunham a todas as conveniências do ensino. Agora, livres das distorções a que estavam submetidas as universidades, encontrareis o ambiente próprio à fecunda convivência entre mestres e discípulos, todos voltados para o desenvolvimento da cultura nacional. (Idem, ibid.).

O discurso foi disciplinador, mas Castelo Branco não foi tão enfático quanto os outros oradores, em glorificar a pretensa revolução. Em conjunto, os três discursos aqui mencionados acabaram por traduzir o que bem sintetizou Chauí (2000, p. 41):

A ditadura, desde o golpe de Estado de 1964, deu a si mesma três tarefas: a integração nacional (a consolidação da nação contra sua fragmentação e dispersão em interesses regionais), a segurança nacional (contra o inimigo interno e externo, isto é, a ação repressiva do Estado na luta de classes) e o desenvolvimento nacional (nos moldes das nações democráticas ocidentais cristãs, isto é, capitalistas).

Como o opúsculo que continha os discursos veio a público com a finalidade de apresentar o pensamento do novo Governo sobre "o problema da Universidade e suas implicâncias no desenvolvimento econômico, na paz social e no futuro da nacionalidade" (MEC, 1964), foi muito pouco o que realmente se disse.

\section{Discursos, fatos e atos}

Em estudo anterior, mais amplo do que o presente texto, pudemos consultar outros pronunciamentos da ditadura civil-militar proferidos no transcorrer do ano de 1964 e, no que dizia respeito à universidade, ao movimento estudantil e aos professores foi possível concluir:

O governo que havia estabelecido uma revolução por decreto colocouse como fundador da universidade brasileira, saneador de idéias e disciplinador dos homens. Tudo isso, sempre proclamando um só objetivo: evitar a revolução comunista e resolver o que considerava o problema real do país, ou seja, o aumento da produtividade através da 
técnica aplicada à produção. A história veio mostrar, entretanto, que enquanto pretensos fundadores da universidade brasileira, os governos militares se revelariam, em verdade, apenas os modernizadores autoritários daquela instituição; como saneadores das idéias, se constituiriam nos patrulheiros ideológicos dos mais reacionários, e, enquanto disciplinadores de homens, se tornariam especialistas na repressão. (Sanfelice, 1986, p. 86)

Mais do que os discursos, as medidas governamentais da ditadura parida pelo movimento civil-militar de 1964 efetivavam, de fato, a reforma universitária que Florestan Fernandes chamaria de "consentida". As desconfianças estudantis quanto às intenções do ministro da Educação, professor Flávio Suplicy de Lacerda, não estavam equivocadas.

O Congresso Nacional aprovou a Lei n. 4.464, de 9 de novembro de 1964 (Diário Oficial da Uniāo, 11 nov. 1964, p. 169), dispondo sobre os órgãos de representação dos estudantes, agora totalmente tutelados pelas instituiçôes universitárias e governamentais. A Lei ficou conhecida por Lei Suplicy de Lacerda e, na prática, visava o controle, o esvaziamento ou a extinção do movimento estudantil.

No final daquele ano de 1964 e no início de 1965, ocorreu o Simpósio sobre a Reforma da Educação, organizado pelo Instituto de Pesquisas e Estudos Sociais (IPES-GB), uma instituição envolvida no golpe. Intelectuais e empresários ali reunidos tiraram diretrizes para o ensino superior e continuaram a atuar como grupo de pressão na formulação das políticas educacionais.

Em 31 de março de 1965, o Presidente instalou a I Conferência Nacional de Educação em Brasília e considerou satisfatórias as medidas tomadas pelo MEC em um ano de governo. Teriam sido restauradas a autoridade das chefias administrativas, a autenticidade das decisões, a austeridade do emprego dos recursos públicos e as escolas funcionavam com normalidade (Castelo Branco, 1965, p. 165-67). O outro lado da moeda não era mostrado. Editores estavam presos por delito de opinião, intelectuais clamavam pelo direito de se expressarem livremente, a UnB encontrava-se em profunda crise, sob intervenção, sendo desmontada e novamente ocupada pela Polícia Militar, os estudantes da USP em greve, o Conjunto Residencial da USP (CRUSP) invadido pela polícia e depredado, entre outros fatos da maior gravidade. 
Enquanto o MEC firmava acordo, em 23 de junho de 1965, com a United States Agency for International Development (USAID), para a implantação da reforma universitária, o ministro da Educação se especializava em aterrorizar o movimento estudantil. Era tal sua ferocidade vocabular que Otto Maria Carpeau, em editorial do Correio da Manhă, de $1^{\circ}$ de setembro de 1965, referiu-se a ele como alguém que desconhecia as matérias sobre as quais opinava. Mas o ministro não alterou seus discursos e muito menos suas ações para o fechamento de órgãos estudantis. A universidade brasileira, cada vez mais em crise, demonstrava outra das suas faces e de modo muito semelhante àquele congraçamento ocorrido no V Fórum, entre reitores, administradores universitários, intelectuais, professores e o poder central da ditadura civil-militar. Muitos sujeitos, vinculados às instituições universitárias, de dentro delas ou cooptados para diferentes cargos, passaram a colaborar direta ou indiretamente com a repressão. Em Manifesto, assinado pelos diretores da UNE, os intelectuais foram admoestados: "Queremos lembrar-lhes que a história é irreversível, e que o julgamento das gerações é severo. E que ideais se conquistam lutando, resistindo e sofrendo" (Castilho, s.d.).

Um resumo dos fatos, ainda daquele início do que seriam duas décadas da ditadura civil-militar, aponta para o seguinte: realização de eleiçôes diretas para os cargos de governadores dos estados, em 3 de outubro de 1965, com resultados desfavoráveis aos sustentadores do movimento de 1964; a reação da ditadura com a edição do Ato Institucional n. 2, de 27 de outubro de 1965; o ditador no posto de Presidente teve seu mandato inicial ampliado; a substituição de Castelo Branco por Costa e Silva se deu com um pleito indireto; os partidos políticos foram extintos; o ditador, através do Ato Complementar n. 4, de 20 de novembro de 1965, criou dois partidos políticos: Aliança Renovadora Nacional (arena) e Movimento Democrático Brasileiro (MDB); o chamado Comando Supremo da Revolução ficou isento de ter seus atos apreciados pela Poder Judiciário; os cidadãos civis tornaramse passíveis de serem submetidos aos tribunais militares; o Presidente adquiriu poderes para, sem observar as limitações constitucionais, suspender direitos políticos dos cidadãos por dez anos e cassar mandatos legislativos de todos os níveis. Os cidadãos foram advertidos:

A Revolução está viva e não retrocede. Tem promovido reformas e vai continuar a empreendê-las, insistindo patrioticamente em seus propósitos de 
recuperação econômica, financeira, política e moral do Brasil. Para isto precisa de tranquilidade. Agitadores de vários matizes e elementos da situação eliminada teimam, entretanto, em se valer do fato de haver ela reduzido a curto tempo o seu período de indispensável restrição a certas garantias constitucionais, e já ameaçam e desafiam a própria ordem revolucionária, precisamente no momento em que esta, atenta aos problemas administrativos, procura colocar o povo na prática e na disciplina do exercício democrático. (Campanhole \& Campanhole, 1981, p. 312-320)

No início do ano de 1966, mais um golpe foi dado pela ditadura. O Ato Institucional n. 3, de 5 de fevereiro, tornava indiretas também as eleiçôes de governadores e vice-governadores dos estados. Além disso, os prefeitos dos municípios das capitais passavam a ser nomeados pelos governadores do estado.

Há muitos registros de época sobre as reações e as tentativas de algumas resistências aos desmandos autoritários da ditadura. Bispos da Igreja Católica, intelectuais, o Movimento Estudantil, revistas e jornais questionavam e ensaiavam explicaçōes para os rumos que a ditadura imprimia aos acontecimentos. Concomitantemente, estes mesmos sujeitos e canais de comunicação informavam sobre a prisão de intelectuais, o abandono que muitos deles tiveram que fazer do país, a repressão crescente sobre a UNE, o desmonte do quadro docente da UnB e as investidas contra livros apreendidos.

Em julho de 1966, a UnE realizou o seu XXVIII Congresso, em Belo Horizonte, apesar de toda a repressão. Os estudantes produziram dois expressivos documentos: o "Plano de Ação" e a "Declaração de Princípios". No "Plano de Ação", uma síntese das reivindicações estudantis foi apresentada: luta pela reforma universitária e revogação do acordo MEC-USAID; luta contra a transformação das universidades federais em fundaçóes particulares e em favor da escola pública gratuita; luta para a alfabetização de todo o povo, por um ensino secundário voltado para a formação profissional e pela revogação da Lei Suplicy. Na seqüência do documento e na "Declaração de Princípios", realizou-se uma sugestiva análise da conjuntura política, econômica e social local, bem como de sua relação com o imperialismo.

Quando Moniz de Aragão assumiu como ministro da Educação, os professores foram considerados responsáveis pelos problemas da universidade brasileira e pela agitação estudantil. Os professores foram 
exortados a ajudar o governo e a se constituir em mediadores entre aquele e os estudantes (Brito, s.d., p. 227-30). Contudo, o confronto entre o governo e os estudantes acirrou-se de tal forma que o dia 22 de setembro de 1966, o Dia Nacional de Luta contra a Ditadura, assim declarado pelo Movimento Estudantil, constituiu-se no clímax do próprio Movimento no período imediatamente posterior a 1964.

As iniciativas repressivas da ditadura ampliaram-se de forma substantiva e, pelo Decreto-Lei n. 53, de 18 de novembro de 1966, fixaram-se Princípios e Normas de Organização para as Universidades Federais. Naquele ano, ainda se assistiria à ditadura editando seu Ato Institucional n. 4, convocando extraordinariamente o Congresso Nacional para votar e promulgar uma nova Constituição, cujo projeto fora apresentado pelo próprio Presidente da República. Paralelamente, legislação voraz regulou a liberdade de manifestação do pensamento e da informação (Diário Oficial da União, 19 fev. 1967, p. 1657-1662), definiu os crimes contra a segurança nacional, a ordem política e social (Diário Oficial da União, 13 mar. 1967, p. 2993-2995). A Une, legalmente, estava extinta, mas continuava funcionando de forma clandestina e prova disso foi a realização do seu Xxix Congresso, responsável pela emissão da "Carta Política da UNE" (Sanfelice, 1986, p. 135-141).

Os anos de 1967 e 1968 seriam repletos de enfrentamentos: estudantes foram mortos ou presos; as passeatas ganharam manchetes; a "Batalha da Rua Maria Antonia", de forma emblemática, colocou estudantes da Filosofia da USP em conflito com os estudantes do Mackenzie e as denúncias na Câmara Federal pelo deputado Maurílio F. Lima, do caso Parasar, um plano dos oficiais da Aeronáutica para usar a Força Aérea Brasileira (FAB) em missōes de assassinatos das principais lideranças que resistiam à ditadura, atirando-as ao mar, após seqüestro, são alguns exemplos. $O$ frustrado XXX Congresso da UNE, com quase 800 estudantes presos, foi apenas mais um desdobramento de toda a repressão, embora anos muito mais negros ainda viessem. O ano de 1968 chegou ao seu final com o Congresso Nacional fechado à força, após o deputado Márcio Moreira Alves ter se manifestado a favor de um boicote popular às comemorações de 7 de Setembro. E, com um golpe profundo à cidadania já tão vilipendiada, a ditadura ainda editou, em 13 de dezembro, o Ato Institucional n. 5 (AI-5), uma expressão soberba do autoritarismo. 
Vamos nos deter neste ponto quanto ao resumo dos fatos e pela limitação imposta por este espaço de publicação, mas esperamos ter traduzido um pouco daquele contexto e do qual queremos privilegiar, agora, o I Fórum de Professores.

\section{O I Fórum de Professores}

Pouco antes da edição da Lei n. 5.540, de 28 de novembro de 1968, que instituiu os princípios para a organização e funcionamento do ensino superior e sua articulação com a escola média, realizou-se o I Fórum de Professores sobre a "Política educacional do Governo", de 11 a 13 de outubro de 1968. O Fórum foi organizado por associações de professores universitários, secundaristas e primários do Rio de Janeiro (GB) e aconteceu no auditório do Colégio São Vicente de Paula. O professor Florestan Fernandes proferiu a conferência de abertura do Fórum e fez uma reflexão sobre os fatos imediatos que vinham constituindo o cenário. Passamos a destacar alguns pontos de maior relevância.

Florestan Fernandes entendia que a reforma universitária, surgida tardiamente no Brasil, era um movimento de estudantes e de professores que acabou por repercutir no Governo Federal. A prova disso teria sido o Decreto n. 62.937/68, criando o Grupo de Trabalho (GT) com a missão de estudar a forma da universidade brasileira, torná-la eficiente, modernizada, com flexibilidade administrativa e formando recursos humanos de alto nível para o desenvolvimento do país. O Relatório do GT passou a ser objeto de análise do conferencista. ${ }^{6}$

A primeira observação de Fernandes recaiu sobre os membros do GT que assinaram o Relatório: o ministro da Educação, um professor de universidade federal e presidente do Conselho Nacional de Pesquisas; um padre, vice-reitor de uma PUC e assessor da Associação dos Dirigentes Cristãos de Empresas; um reitor de uma universidade estadual; um representante do ministro do Planejamento e um do ministro da Fazenda; um catedrático de uma renomada universidade pública paulista; um ex-professor, ex-diretor de faculdade e ex-reitor de uma universidade federal do Nordeste, membro do Conselho Federal de Educação, e um ex-professor e ex-diretor de faculdade de outra universidade do Nordeste, também membro do Conselho Federal de Educação. Dois estudantes indicados para o GT não participaram 
dos trabalhos (Cunha, 1988, p. 241). Um GT formado por “(...) técnicos, educadores e cientistas de reconhecida competência e de grande prestígio" (Fernandes, 1974, p. 2). Fernandes toca em um ponto nevrálgico:

(...) o GT recebia seu mandato de um Governo destituído de legitimidade e que não encarna a vontade da Nação, mas dos círculos conservadores que empalmaram o poder, através de um golpe de Estado militar. Por mais respeitáveis ou bem intencionados que sejam os seus componentes, eles se converteram, individual e coletivamente, em delegados dos detentores do poder e em arautos de uma reforma universitária consentida. (Idem, ibid., p. 2)

Criticando a falta de sintonia entre os membros do GT, em pontos cruciais da reforma universitária, Fernandes assume o tom de denúncia: "O GT deu-se por satisfeito com as inovaçōes improvisadas do Governo Castelo Branco (...)", numa menção ao fato de que o mesmo acatou, nos anteprojetos que apresentou, os Decretos-Lei n. 53, de 18 de novembro de 1966, e n. 252, de 28 de fevereiro de 1967.7 Enfaticamente, "o GT não encaminhou nenhuma reforma universitária. Endossou e consolidou a reforma no papel do Governo Castelo Branco, implementando-a com instrumentos legais e dotando-a de recursos materiais que pretendem incutir-lhe alguma eficácia prática”.

Percebemos, ao longo do texto-conferência, uma preocupação do autor em dimensionar as contribuiçóes que reconheceu terem sido dadas pelo GT, os limites que identificou no mesmo, mas acima de tudo sua preocupação política com a atuação dos intelectuais naquelas açōes da ditadura civil-militar em conduzir, a partir do governo e do Estado, uma reforma universitária consentida. Não pretendemos entrar no mérito das contribuições e limites que foram assinalados, uma vez que avaliações desta ordem já foram realizadas sobejamente. Interessa-nos, sim, acompanhar a conotação política que a fala de Florestan Fernandes suscitava, no que dizia respeito à participação dos intelectuais, cientistas e professores no processo então em pauta. É por este prisma que enfatizamos a leitura do documento: "O fato de tantos intelectuais de escola terem aceitado, avidamente, os papéis decorrentes de uma transição conservadora é, em si mesmo, algo relevante e que exige um exame crítico" (Fernandes, 1974, p. 3). 
Florestan Fernandes identificou no Relatório do GT uma estratégia expositiva que arrebatava a bandeira da reforma universitária das mãos de um movimento de grande vitalidade política para a iniciativa e atuação do Governo. Fez avanços teóricos, abstratos e verbais, tudo, como mero expediente literário qualificado. Quando o Relatório passou para o plano da formulação das normas e princípios que deveriam reger o ensino superior, revelou-se grande defasagem, porque se expressou uma atuação conservadora que, ameaçada, foi "compelida a assumir o controle político dos processos de modernização cultural e de inovação institucional" (idem, ibid., p. 5).

Perante situaçōes concretas, é normal que "estratos das camadas conservadoras" adquiram diferentes níveis de consciência da situação histórica, segundo as palavras de Fernandes. Para ele, os intelectuais são os que podem ir mais longe nestas situaçôes, por serem menos isolados culturalmente. Contudo, não é por isso que intelectuais conservadores cheguem ou possam atuar com maior discernimento político. Era esta, então, a chave para compreender a presença daqueles intelectuais nas açôes do governo da ditadura civil-militar:

Por mais coerentes, íntegros e lúcidos que sejam os intelectuais pertencentes ou identificados com os interesses políticos conservadores, eles não podem romper essa barreira. Palmilham, então, um triste destino humano. No campo do conhecimento puro e da consciência abstrata, podem ir tão longe quanto a sua época e a sua geração. No plano do político, estão condenados à lógica e à dinâmica do pensamento e da ação conservadores, não podendo ultrapassar as suas acanhadas fronteiras. Tudo se desenrola como se eles compartilhassem, no íntimo, do afã de resolver os problemas do modo melhor possível; e aceitassem, na prática, as "soluçôes concretas" compatíveis com o equilíbrio existente entre a ordem social estabelecida e o monopólio conservador do poder. (Idem, ibid., p. 6)

Os intelectuais participantes do GT teriam se comportado exatamente desta forma e, para Fernandes (op. cit., p. 8), não bastava criticálos atenta e objetivamente nos limites do desmascaramento ideológico. Era preciso mais: "impóe-se o repúdio franco e decidido".

A capitulação dos intelectuais, que introduzem a transação conservadora no âmago dos processos políticos que permeiam a revolução nacional da sociedade brasileira, e em particular quando isso se dá na esfera do ensino 
e da cultura, precisa ser repelida com extrema firmeza e inflexibilidade. (Fernandes, 1974, p. 8)

O autor da aula inaugural esmiúça, a seguir, o encobertamento operado pelo GT quanto ao significado dos fatos pseudo-revolucionários. O GT teria se tornado em arauto de uma causa que não podia nem queria defender. Saía "do terreno da imprudência para se cair no da impudência!". A questão central colocada por Fernandes foi a tentativa de se fazer um discurso que supunha avançar na reforma universitária, quando, na prática, o poder conservador recém-definido ostensivamente indicava que não era este o caminho escolhido. E o caminho escolhido era agora referendado pelo GT.

Apesar de todo esse posicionamento, Florestan Fernandes fez, na seqüência, uma detalhada análise do conteúdo do Relatório do GT, em seus muitos outros aspectos que não nos interessam neste momento.

\section{Considerações}

O breve espaço ocupado por este texto não foi dedicado a fazer um estudo da reforma universitária dos anos de 1960 e nem mesmo do Movimento Estudantil daquela década, pois esses temas vêm sendo estudados por literatura especializada. A reforma universitária, o Movimento Estudantil e as relaçôes mútuas que lá se estabeleceram vinham sendo tecidos desde décadas anteriores. Buscamos apontar, entretanto, o seguinte eixo de raciocínio: a ditadura civil-militar viabilizou uma reforma universitária que expressava a histórica sociedade autoritária, modernizando-se no âmbito do modo de produção capitalista, agora protagonizado por um autoritarismo exacerbado. Militares e civis comandavam o autoritarismo, que buscava legitimar-se por meio de legislação espúria e fundando fatos, como que criando mitos. Não havia ocorrido uma revolução, mas sim uma reação conservadora ao reformismo nacionalista, este sim antes em prática.

Por outro lado, entre os partícipes da farsa, não-revolucionária, muitas instituiçóes civis, muitos intelectuais, muitos professores e estudantes. O mesmo ocorria nas tentativas de resistência. Ao se considerar os discursos oficiais do v Fórum Universitário e a conferência de abertura proferida por Florestan Fernandes no I Fórum de Professores, assistimos ao embate que diferentes posições ideológicas ou práticas 
suscitavam. É gritante a fala de Florestan Fernandes, como se dissesse: o que intelectuais, professores, reitores estão fazendo aí no cerne do autoritarismo da ditadura civil-militar? Por que exatamente eles queriam enfiar goela abaixo dos demais a reforma universitária, que representava os interesses do capital e do imperialismo? Florestan Fernandes buscou suas explicações que resumidamente indicamos acima.

Os representantes da ditadura civil-militar de 1964 não foram inócuos. Eles implementaram o projeto que haviam encampado dos industriais e setores financeiros, de parte dos próprios militares que desenvolveram a doutrina da "segurança" e do "desenvolvimento", superando inclusive as elites mais conservadoras do país que, se úteis no combate ao fantasma da "comunização" e da reforma agrária, deixaram de ter hegemonia no processo subseqüente à derrubada do governo de João Goulart. A vitória do projeto de modernização conservadora colocou fim às possibilidades de se avançar com as reformas de base. ${ }^{8}$

A reforma universitária e o ideário do Movimento Estudantil, para muitos, estavam relacionados de forma direta às reformas de base. O ideário do Movimento de 1964 condicionou-os, tanto quanto possível, ao seu projeto político, social, econômico e ideológico.

Os intelectuais, professores, estudantes, ministros, reitores dividiram-se. Os agentes envolvidos, classes sociais, instituiçôes e outros buscaram cooptá-los. De há muito, parte deles já se encontrava nas lides do reacionarismo conservador pré-64. Outros fizeram parte do projeto reformista e houve aqueles que urdiram a pílula da reforma universitária consentida. Contra os últimos, Florestan Fernandes ${ }^{9}$ voltou suas indagações, que não se tornaram anacrônicas para os dias de hoje, quando a educação e a universidade vão sendo reformadas pelas Agências, sob o manto do neoliberalismo mercantil e privatista, com a participação de dezenas de intelectuais que atuam em prol da sua hegemonia e em busca de um consenso bestializante.

Recebido em novembro de 2007 e aprovado em julho de 2008.

\section{Notas}

1. Bolchevizar é utilizado aqui para expressar uma possível submissão do governo de João Goulart à dominação da doutrina comunista, conforme expressa o Dicionário Houaiss da língua portuguesa. 
2. Pela ordem constitucional então vigente, João Goulart, vice-presidente, deveria simplesmente assumir a presidência, após a renúncia de Jânio Quadros. Dada as resistências à sua posse, a solução foi um golpe-branco que instituiu o regime parlamentarista no Brasil e sob o qual João Goulart recebeu a faixa presidencial em 7 de setembro de 1961. Após o plebiscito de 6 de janeiro de 1963, numa proporção de 5 votos para 1, o parlamentarismo foi rejeitado, tendo votado cerca de treze milhões de eleitores. Em 23 de janeiro de 1963, João Goulart reassumia com plenos poderes presidencialistas, conforme a Constituição de 1946.

3. Cunha (1983) indica: "O Fórum Universitário, criado por portaria do Ministério da Educação em fevereiro de 1962, para servir de assessoria ao ministro, seu presidente, era constituído dos reitores de todas as universidades, do Diretor de Ensino Superior e de um representante da UNE. Em junho de 1963, portaria do ministro Paulo de Tarso incluiu entre os participantes do Fórum os presidentes de um terço dos Diretórios Centrais de Estudantes, a serem indicados pela UNE, em regime de rodízio. A derrota dos estudantes na luta por um terço de representantes nos órgãos colegiados das universidades foi 'compensada' ou 'vingada' por igual participação no Fórum Universitário que reunia, justamente, os reitores antagonistas. Em novembro de 1964, portaria do ministro Suplicy de Lacerda aprovou novo regimento do Fórum Universitário, restringindo suas atividades e incluindo um representante indicado pelo órgão nacional de representação estudantil, o Diretório Nacional de Estudantes, a ser organizado conforme as diretrizes da 'Lei Suplicy' (Lei n. 4.464, promulgada no mesmo mês)".

4. Chauí (2000) esclarece, de forma muito perspicaz, o sentido do qual aqui nos apropriamos ao nos referirmos a um mito fundador e não à formação, que seria a história propriamente dita.

5. Referimo-nos como crasso cochilo o fato de se considerar uma reforma legal revolucionária a Lei n. 4.024, de 20 de dezembro de 1961, sancionada exatamente por João Goulart, contra quem o movimento civil-militar de 1964 proclamou uma revolução. Parecia ser um reconhecimento indevido. Por outro lado, há grande coerência em se defender aquela legislação, uma vez que, após tantos anos de tramitação, a mesma apresentou-se conservadora e distante das posições que vinham sendo defendidas por intelectuais, pelo movimento estudantil, por movimentos sociais operários e setores progressistas.

6. Lembramos que, desde o final de 1967 , o governo da ditadura civil-militar do movimento de 64 já havia criado outra comissão formada por coronéis, professores e um promotor, visando encontrar respostas, no auge da crise estudantil, para encaminhamentos possíveis. O relatório final da comissão ficou conhecido como Relatório Meira Matos, nome do coronel que presidira a comissão. Este relatório, bem como aquele ao qual Florestan Fernandes se refere, foram objetos de dissecamento em várias obras.

7. O Decreto-Lei n. 53 já foi mencionado. O Decreto-Lei n. 252 dava continuidade àquele nas providências para a reforma universitária promovida pelo Governo.

8. "Neste quadro, não houve novidade no fato de os Estados Unidos tentarem - e conseguirem - influenciar o que acontecia no Brasil. A participação norte-americana no movimento contra o governo Goulart ocorreu não só através da desestabilização (o estrangulamento econômico com o respaldo da propaganda, visando enfraquecer politicamente o governo), como na deposição do presidente. Os exemplos mais notórios foram a campanha religiosa anticomunista do padre Patrick Peyton e a operação naval 'Brother San', que daria sustentação militar aos revoltosos em caso de necessidade" (FGV-CPDOC, 2007).

9. "Florestan Fernandes nasceu em 22 de julho de 1920 e faleceu em 10 de agosto de 1995, na cidade de São Paulo. Em 1964, foi preso político no presídio do Exército, em São Paulo. 
Solto, foi professor catedrático na USP, efetivado por concursos de títulos e provas a partir de 23 de fevereiro de 1965. Teve prisão preventiva decretada ainda em 1965. Em 1966, foi impetrado habeas corpus por seu advogado, Dr. Saulo Ramos. Asilou-se no Canadá em 1969 e 1970. Foi afastado de suas atividades na Usp, através de aposentadoria compulsória, em 24 de abril de 1969, através do Ato Institucional n. 5, pela Ditadura Militar”. Em fins de 1972 regressou ao Brasil, onde teve extensa carreira como professor, intelectual, autor e político (disponível em: <http://br.geocities. com/marrua2000/florestan/ florestan.html>. Acesso em: 2 abr. 2007).

\section{Referências}

ATOS INSTITUCIONAIS n. 1, 2, 3, 4, 5. In: CAmpanhole, A.; Campanhole, H.L. Constituições do Brasil. São Paulo: Atlas, 1981.

BANDEIRA, M. O governo João Goulart: as lutas sociais no Brasil 1961-1964. Rio de Janeiro: Civilização Brasileira, 1978.

BENEVIDES, M.V. O governo Jânio Quadros. São Paulo: Brasiliense, 1981.

BRASIL. Diário Oficial da União, Brasília, DF, 1967, p. 1657-1662.

BRASIL. Diário Oficial da União, Brasília, DF, 1967, p. 2993-2995.

BRASIL. Ministério da Educação. Diretoria do Ensino Superior. $A$ universidade e a revolução nacional. Brasília, DF: MEC; Secretaria do Fórum Universitário, 1964.

BRITO, S. Documentário: a crise entre estudantes e governo no Brasil. Rio de Janeiro: Paz \& Terra, [s.d.]. v. 3, p. 191-240.

CASTELO BRANCO, H. Pela democratização do ensino. Revista Brasileira de Estudos Pedagógicos, Rio de Janeiro, v. 43, n. 98, p. 165-167, abr./jun. 1965.

CASTIlHO, A. (Org.). Apesar de tudo: une Revista; elementos para uma história da UNE. São Paulo: Guaraná; DCE-Livre USP "Alexandre Vanuchi Leme", s.d.

CHAUI, M. Brasil: mito fundador e sociedade autoritária. São Paulo: Fundação Perseu Abramo, 2000.

CUNHA, L.A. A universidade critica. Rio de Janeiro: Francisco Alves, 1983. 
CUNHA, L.A. A universidade reformada. Rio de Janeiro: Francisco Alves, 1988.

O CRUZEIRO. 10 abr. 1964. Edição extra. Disponível em: <www.memoriaviva.com.br/cruzeiro/10041964/199464_3.htm>. Acesso em: 31 mar. 2007. (digitalizado).

DICIONÁRIO HISTÓRICO-BIOGRÁFICO BRASILEIRO. Disponível em: <www.cpdoc.fgv.br/comum/html/index.html>. Acesso em: 2 abr. 2007. (Digitalizado)

FERNANDES, F. Os dilemas da reforma universitária consentida. Debate \& Crítica, São Paulo, n. 2, jan./jun. 1974.

ROMANELLI, O.O. História da educação no Brasil. Petrópolis: Vozes, 1987.

SANFELICE, J.L. Movimento estudantil: a UNE na resistência ao golpe de 64. São Paulo: Cortez; Campinas: Autores Associados, 1986.

TOlEDO, C.N. O governo Goulart e o golpe de 64. São Paulo: Brasiliense, 1983. 